ADDIN, Vol. 10, No. 1, Februari 2016

\title{
RADIKALISME DALAM DUNIA PENDIDIKAN
}

\section{Saekan Muchith}

STAIN Kudus, Jawa Tengah, Indonesia

mubsaekan@gmail.com

\section{Abstrak}

Tujuan pendidikan adalah memanusiakan manusia dengan cara yang manusiawi sehingga terwujud tatanan saling menghormati dan menghargai. Idealisme tersebutbelum sepenubny a berjalan sesuai harapan. Selama ini dilembaga pendidikan masih sering terjadi kekerasan dan intimidasi yang dikenal dengan istilah radikalisme dalam pendidikan. Radikalisme dalam pendidikan bisa muncul dari guru kepada siswa, dari pimpinan sekolah kepada guru, dan dari masyarakat atau orang tua siswa kepada guru dan sekolah dengan berbagai macam bentuk tindakan intimidasi. Hal ini disebabkan oleh lemahnya posisi guru sebagai jabatan profesi karena belum memiliki perlindungan sesuai dengan amanah Pasal 39 ayat 1-5 Undang-undangNomor 14 tahun 2005 Tentang Guru dan Dosen bahwa setiap guru harus memperoleh perlindungan bukum, profesi,serta perlindungan kesehatan dan keselamatan kerja. Akibatnya, guru seringkali mendapat perlakuan yang tidak proporsional dan guru juga tidake bisa berbuat banyak. untuk melakukan perlindungan terbadap dirinya. Dengan berlakunya undang-undang perlindungan guru tersebut,tindakan guru yang dianggap kurang tepat bisa diselesaikan secara tuntas melalui regulasi peraturan profesi.Salah satu cara untuk. mengurangi munculny a radikalisme dalam pendidikan harus dimulai dengan memberlakukan amanah Undangundang Guru dan Dosen, khususnya dalam hal perlindungan kepada 
M. Saekan Muchith

guru dalam menjalankan tugas profesinya.

Kata Kunci: Radikalisme, Pendidikan.

\section{Abstract}

THE RADICALISM IN EDUCATION: The purpose of education is to humanize human beings in a humane manner to realize the order of honor and respect. This Idealism has not fully run as we expected. During this time, the institution of education is rampant to the violence and intimidation known as radicalism in education. Radicalism in education comes from teachers to students, from the headmaster to the teachers, and the community or parents of students to teachers and schools with various forms of intimidation. This is due to the weak position of the teacher as a professional occupation because it has no protection in accordance with the mandate of Article 39, paragraph 1-5, the constitution Number 14, 2005 on Teachers and Lecturers that every teacher should obtain the legal protection, profession, as well as the protection of health and safety. As a result, teachers are often treated disproportionate and they also have no authority to make the protection of him. With the enforcement of protection laws of the teacher, the teacher's behavior that is considered less precise could be solved completely through the regulation of profession. One of the ways to reduce the appearance of radicalism in education should be started by enforcing the mandate of the Law on Teachers and Lecturers, especially in terms of protection to teachers in carrying out his profession.

Keywords: Radicalism, Education.

\section{A. Pendahuluan}

Pendidikan adalah aspek yang sangat vital bagi kehidupan manusia. Hal yang dikerjakan setiap manusia, mulai dari bangun tidur sampai meninggal dunia, adalah bagian dari proses dan sekaligus produk pendidikan. Ki Hadjar Dewantoro menyebutnya sebagai life long education yang diartikan sebagai proses pendidikan sepanjang hayat. Benjamin Samuel Bloommemiliki konsep taksonomi pendidikan yang meliputi tiga ranah, yaitu kognitif, afektif, dan psikomotorik. Kognitif adalah hal-hal yang berkaitan dengan kecerdasan atau keterampilan intelektual (akal pikiran), 
afektif adalah hal-hal yang berkitan dengan kecerdasan atau keterampilan sikap kepribadian (etika/sopan santun), dan psikomotorik adalah hal-hal yang berkaitan dengan kecerdasan atau keterampilan motorik/mekanik(olah fisik).

Pendidikan bersifat integratif dan komprehensif, artinya memiliki aspek atau materi yang beraneka ragam dan saling berkaitan antara materi satu dengan lainnya. Pendidikan tidak hanya mengarahkan kualitas pikiran saja, tetapi juga menyangkut etika dan kecerdasan mekanik atau otot. Dengan kata lain, ukuran keberhasilan pendidikan tidak cukup dilihat dari keberhasilan melahirkan keterampilan kognitif atau afektif atau psikomotorik saja, melainkan ketiga ranah tersebut harus tercapai secara utuh dan sempurna.

Jean Piaget dalam teori perkembangan kognitif mengatakan bahwa pendidikan harus sesuai dengan perkembangan kemanusiaan. Artinya, pendidikan harus selalu memerhatikan dua hal sekaligus, yaitu perkembangan atau kemampuan yang dimiliki setiap manusia dan memerhatikan dinamika yang berkembang di tengah masyarakat yang meliputi ilmu pengetahuan, teknologi, dan budaya. Seiring dengan dinamika kehidupan yang ditandai dengan semakin canggihnya peralatan, semakin kompleksnya problem kehidupan, dan semakin tingginya tuntutan masyarakat, maka sudah seharusnya diikuti dengan kecerdasan dalam melakukan proses pendidikan agar pendidikan tidak tertinggal dengan dinamika kehidupan sosial.

Menurut kewajaran logika manusia, semakin lengkap peralatan akibat perkembangan dan dinamika kehidupan manusia, maka pendidikan akan semakin sukses dalam membimbing dan mengarahkan manusia untuk menjadi manusia yang baik. Kemajuan suatu peradaban bangsa ditandai dengan mudahnya mengakses informasi karena banyaknya media sosial, kemudahan manusia melakukan komunikasi walaupun jaraknya berjauhan, serta adanya tuntutan demokrasi dan transparansi dalam menjalankan tugas dan fungsinya. Ada yang mengatakan bahwa maju atau tidaknya suatu bangsa dilihat dari proses atau praktik demokrasi. Oleh sebab itu,pada tahun 1998, seluruh elemen 


\section{Saekan Muchith}

bangsa Indonesia yang dimotori oleh gerakan mahasiswa menuntut agar Indonesia melakukan reformasi politik dan birokrasi dalam arti melakukan perubahan dari sistem otoriter menjadi sistem demokrasi. Akhirnya tuntutan reformasi dikabulkan sehingga bangsa Indonesia melakukan perubahan secara total dalam sistem demokrasi. Mulai dari sistem pemilihan pemimpin yang semula ditunjuk oleh Majelis Permusyawaratan Rakyat (MPR) diubahmelalui pemilihan langsung, dari karakter pemimpin yang semula elitis menjadi profil pemimpin yang merakyat, dari sistem pelaksanaan birokrasi pemerintahan yang tertutup menjadi terbuka atau transparan.

Tuntutan reformasi dalam sistem sosial politik belum sepenuhnyaberjalanlancarsesuaiharapan,adasebagianyangberhasil dan ada sebagian yang tidakberhasil. Sebagian yang tidakberhasil disebabkan karena adanya hak dan kewajiban antarmanusia yang tumpang tindih sehingga menimbulkan problem baru dalam kehidupan sosial. Dalam dunia pendidikan masih banyak praktik pelaksanaan hak dan kewajiban yang tidak proporsional sehingga menimbulkan persoalan baru bagi pendidikan. Misalnya, masyarakat atau orang tua masih banyak yang menuntut secara membabi buta akan keberhasilan anaknya dalam menempuh proses pendidikan. Jika anaknya gagal dalam pendidikan, seakanakan menjadi tanggung jawab guru saja. Akibat transparansi penegakan hukum, banyak guru yang memperoleh ancaman atau intimidasi dari pihaklain seperti orang tua siswa. Tindakan guru melakukan hukuman fisik kepada siswa selalu dikaitkan dengan persoalan hukum pidana umum. Dengan kata lain, sedikit saja guru melakukan kesalahan dalam menjalankan tugasnya, maka ancaman pidana umum telah mengintainya. Ada hal yang kurang proporsional, orang tua dan guru atau pihak sekolah kurang melakukan instrospeksi diri terharap kekurangan dankelebihan yang telah dilakukan. Akibatnya, dalam dunia pendidikan sering tersaji kekerasan dan intimidasi, baik kepada guru,guru kepada siswa,maupun orang tua kepada pihak sekolah. Radikalisme tidak hanya terjadidalam aspek sosial, politik, dan keagamaan, melainkan juga terjadi di dunia pendidikan. Dalam artikel ini, akan dibahas bentuk radikalisme dalam dunia pendidikan dan solusinya. 


\section{B. Pembahasan}

\section{Pendidikan}

Pendidikan memiliki tujuan dan fungsi sangat mulia, yaitu memanusiakan manusia, dalam arti menjadikan manusia lebih berperan sebagai manusia, lebih mengetahui serta memahamai nilai-nilai dan hakikat sebagai manusia. Hal ini menjadi penting, karena jika manusia tidak mengetahui dan memahamai nilainilai kemanusiaan, maka akan jatuh ke dalamsifat-sifat hewan atau binatang. Antara manusia dan binatang hakikatnya sama, perbedaannya hanya dalam hal optimalisasi penggunaan rasio atau akal saja. Dalam istilah bahasa Arab dinyatakan, al-insanu bayawanu an-natiqu, manusia adalah hewan yang berpikir. Atau dikatakan juga, buman is animal rational, manusia adalah hewan yang berpikir.

Pendidikan adalah suatu proses yang sangat penting bagi kelangsungan hidup dan kehidupan manusia. Nanang Martono mengatakan bahwa pendidikan adalah tema yang sangat menarik bagi manusia, karena pendidikan adalah sebuah lembaga vital sekaligus menyediakan investasi jangka panjang bagi semua bangsa di dunia. Pendidikan juga dapat dikatakan suatu indikator kemajuan peradaban suatu bangsa. Mengapa demikian?

Menurut Pasal 1 ayat (1) Undang-undangNomor 20 Tahun 2003 Tentang Sistem Pendidikan Nasional, pendidikan adalah usaha sadar dan terencana untuk mewujudkan suasana belajar dan proses pembelajaran agar peserta didik secara aktif mengembangkan potensi dirinya untuk memiliki kekuatan spiritual keagamaan, pengendalian diri, kepribadian, kecerdasan, akhlak mulia, serta keterampilan yang diperlukan bagi dirinya, masyarakat, bangsa dan negara. ${ }^{1}$

Pengertian ini mengandung beberapa makna. Pertama, pendidikan pasti dilakukan secara sadar, dalam arti diketahui sebelum, saat, dan sesudahnya, baik isi, metode, maupun hasil yang akan dicapai. Oleh karena itu, pendidikan pasti didasarkan

\footnotetext{
${ }^{1}$ Undang-undang Nomor 20 Tahun 2003 Tentang Sistem Pendidikan Nasional.
} 


\section{Saekan Muchith}

pada pertimbangan rasional manusia. Kedua, pendidikan sudah dipertimbangkan secara matang dari aspek kekurangan dan kelebihannya, aspek negatif dan positifnya, danjuga aspek baik dan buruknya. Dengan demikian, jika pendidikan banyak menyisakan kekurangan atau dampak negatif, maka tidak perlu dilaksanakan pendidikan atau segera dicari solusi agar memunculkan halhal yang positif. Ketiga, pendidikan harus dan pasti mampu mewujudkan suasana belajar dan proses pembelajaran. Artinya, setiap pendidikan harus mampu mengondisikan berbagai sumber atau elemen untuk mengembangkan potensi yang dimiliki setiap manusia, karena hakikat belajar dan pembelajaran adalah mengembangkan seluruh potensi yang dimiliki melalui berbagai sumber yang ada di sekelilingnya. Keempat, pendidikan harus mampu mengembangkan semua potensi yang ada dalam diri setiap manusia. Potensi manusia secara umum terbagi kedalam tiga hal, yaitu potensi intelektual, potensi moral atau kepribadian, dan potensi motorik. Artinya, pendidikan tidak dibenarkan hanya mengembangkan intelektual yang menafikan moral dan motorik semata atau sebaliknya. Kelima, target pendidikan adalah tercapainya kekuatan spiritual keagamaan, mampu mengendalikan diri, memiliki kepribadian, serta memiliki kecerdasan, akhlak, dan keterampilan yang diperlukan bagi dirinya sendiri, masyarakat, bangsa, dan negara.

Sungguh luar biasa hal yang harus dihasilkan dari proses pendidikan. Melihat proses dan target yang harus dicapai, maka dapat dikatakan bahwa tidak pernah ada suatu proses yang memiliki target indah dan mulia dibandingkan proses pendidikan. Ruang lingkup pendidikan sangat luas dan kompleks. Menueur, sebagaimana dikutip oleh M. Saekan Muchith dalam buku Ilmu Pendidikan Islam, menjelaskan secara rinci bahwa pendidikan setidaknya memiliki lima aspek atau elemen, yaitu: (a) usaha yang dilakukan benar-benar atas dasar kesadaran; (b) ada pendidik atau orangyang membimbing; (c)ada peserta didik, yaituorang yang dibimbing atau orang yang diarahkan; (d) bimbingan benar-benar dimaksudkan untuk mencapai tujuan yang positif; 
(e) dan usaha yang dicapai selalu memberdayakan sarana untuk mengoptimalkan tujuan yang ingin dicapai. ${ }^{2}$

Hal ini sejalan dengan tujuan pendidikan nasional yang dirumuskan dalam Pasal 3 Undang-undang Nomor 20 Tahun 2003 Tentang Sistem Pendidikan Nasional bahwa pendidikan berfungsi mengembangkan kemampuan dan membentuk watak serta peradaban bangsa yang bermartabat dalam rangka mencerdaskankehidupanbangsa, bertujuanuntukberkembangnya potensi peserta didik agar menjadi manusia yangberiman dan bertakwa kepada Tuhan Yang Maha Esa, berakhlak mulia, sehat, berilmu, cakap, kreatif, mandiri, dan menjadi warga negara yang demokratis serta bertanggung jawab. ${ }^{3}$

Menurut Langeveled, sebagaimana dikutip oleh M. Saekan Muchith dalam buku Pendidikan Tanpa Kenyataan, pendidikan adalah proses bimbingan yang dilakukan oleh orang dewasa dengan tujuan untuk mendewasakan orang lain yang dicirikan dengantiga karakteristik umum, yaitu: (a) stabil, yaitu sikap dan kepribadianyang tetap dalam segala situasi dan kondisi, baik kondisi normal, senang, maupun susah; (b) tanggung jawab, yaitu orang yang memiliki kemampuan memberikan argumentasi kuat terhadapapa yang telah dikatakan dan dilaksanakan; (c) mandiri, yaitu kemampuan untuk mengambil keputusan atas dasar kemampuan yang dimiliki sendiri, bukan karena paksaan dari pihak lain. ${ }^{4}$

Profil orang dewasa ini sejalan dengan profil orang yang bertakwa sebagaimana dijelaskan dalam Q.S. Ali Imran [3]: 133134, 'Dan, bersegeralah kamu mencari ampunan dari Tuhanmu dan mendapatkan surga yang luasnya seluas langit dan bumi yang disediakan bagi orang-orang yang bertakwa, yaitu orang yang berinfak baik di waktu lapang maupun sempit dan orang-orang

${ }^{2}$ M. Saekan Muchith, Ilmu Pendidikan Islam (Kudus: STAIN Kudus Press, 2007), hlm. 17.

${ }^{3}$ Undang-undang Nomor 20 Tahun 2003 Tentang Sistem Pendidikan Nasional.

${ }^{4}$ M. Saekan Muchith, Pendidikan Tanpa Kenyataan(Semarang: Unnes Press, 2008). 


\section{Saekan Muchith}

yang menahan amarahnya dan memaafkan kesalahan orang lain. Dan, Allah mencintai orang-orang yang berbuat kebajikan."

Sementara, menurut Ngalim Purwanto (1995), sebagaimana dijelaskan dalam buku Imu Pendidikan Teoritis dan Praktis, dewasa yang merupakan bagian dari target proses pendidikan ditandai dengan beberapa karakteristik, yaitu memilikikekuatan lahir dan batin (jasmani dan rohani), memiliki kemerdekaan, tetap/stabil, kuat, dan tidak tergantung pada pihak lain. ${ }^{5}$

Berdasarkan kriteria umum tersebut, dapat dikatakan bahwa profil atau produk dari pendidikan adalah sosok atau profil manusia yang utuh, komprehensif, dan sempurna, baik dari aspek jasmaniah maupun rohaniah, baik dari aspek keterampilan intelektual maupun keterampilan moral dan motorik, mulai dari cara bicara sampai cara menjalankan tugas atau aktivitas. Pendidikan benar-benar mengajarkan dan membimbing manusia untuk lebih memahami realitas serta mampu menghadapi problem hidup dan kehidupan. Kesalahan dalam praktik pendidikanakan berakibat fatal bagi kelangsungan kehidupan bangsa.

Konsekuensinya, proses pendidikan tidak boleh dikotori dengan sikap dan perilaku yang bertolak belakang dengan visi dan misi pendidikan yang sebenarnya. Semua elemen dalam proses pendidikan harus saling mendukung dan bersinergi secara positif sehingga akan melahirkan kualitas proses dan produk pendidikan sesuai yang dicita-citakan.

\section{Radikalisme}

Radikalisme secara umum dipahami sebagai suatugerakan sosial yang mengarah pada hal-hal yang negatif. Setidaknya persepsi itu yang dikonsepkan oleh Lukman Hakim, Wakil Kepala LIPI, dalam pengantar buku Islam dan Radikalisme di Indonesia. Dari persepsi seperti itu, maka muncul istilah ekstrem, anti Barat, anti Amerika, danteroris. ${ }^{6}$

${ }^{5}$ M. Ngalim Purwanto, Ilmu Pendidikan Teoritis dan Praktis (Bandung: Remaja Rosdakarya,1995), hlm. 15.

${ }^{6}$ Endang Turmudzi dan Riza Sihbudi (ed.), Islam dan Radikalisme di Indonesia(Jakarta: LIPI Press, 2005), hlm. 24. 
Dari perspektif bahasa, sebenarnya radikal jauh berbeda dengan teroris. Sebab, radikal adalah proses secara sungguhsungguh untuk melatih keberhasilan atau cita-cita yang dilakukan dengan cara-cara yang positif. Sementara itu, terorisme berasal dari kata teror yang bermakna menakut-nakuti pihak lain. Oleh sebab itu, teror selalu dilakukan dengan cara-cara negatif dan menakutkan pihak lain.

Seiring dengan dinamika dan pola gerakan kelompokkelompok di masyarakat, akhirnya antara radikal dan teror menjadi satu makna, yaitu radikal merupakan embrio dari gerakan teror. Jika memiliki polapikir radikal, maka berpeluang besar untuk melahirkan aksi teror. Banyak peristiwa di Indonesia dimana terorisme dan radikal menjadi satu sehingga masyarakat umum tidak usah repot-repot membedakan antara radikalisme dan terorisme.

Akar atau sumber radikalisme yang berujung dengan terorisme lebih didominasi dari dogma agama yang dipahami secara sempit oleh pemeluknya. Sebab, dalam doktrin kitab agama, khususnya agama Islam, secara tekstualis dijelaskan tentang teks yang mudah dipahami untuk melahirkan gerakan radikal yang berujung terorisme. Banyak contoh ayat dalam alQur'an yang secara tekstualis berpotensi mengarah pada gerakan radikal, antara lain sebagai berikut.

Pertama, perintah secara tekstual untuk memancung orang kafir apabila bertemu. "Apabila kamu bertemu dengan orang orang kafir (dimedan perang), maka pukullah batang leher mereka. Selanjutnya apabila kamu telah mengalahkan mereka, tawanlah mereka dan setelah itu kamu boleh membebaskan mereka atau menerima tebusan sampai perang selesai. Demikianlah dan sekiranya Allah menghendaki, niscaya Dia membinasakan mereka, tetapi Dia hendak menguji kamu satu sama lainnya. Dan, orang-orang yang gugur di jalan Allah, Allah tidak menyianyiakan amal mereka." (Q.S. Muhammad [47]: 4).

Kedua, perintah perang sampai tidak ada fitnah di muka bumi. "Dan, perangilah mereka itu sampai tidak ada lagi fitnah dan agama hanya bagi Allah semata. Jika mereka berhenti, maka 


\section{Saekan Muchith}

tidak ada lagi permusuhan kecuali terhadap orang-orang zalim.” (Q.S. al-Baqarah [2]: 193).

Ketiga, perintah untuk memerangi orang-orang yang tidak beriman. "Perangilah orang-orang yang tidak beriman kepada Allah dan hari kemudian, mereka yang tidak mengharamkan apa yang telah diharamkan Allah dan rasul-Nya, dan mereka yang tidak beragama dengan agama yang benar (agama Allah) yang telah diberikan kitab, hingga mereka membayar jizyah (pajak) dengan patuh, sedang mereka dalam keadaan tunduk." (Q.S. atTaubah [9]: 29).

Contoh ketiga ayat tersebut secara tekstualis berpotensi melahirkan polapikir radikal yang berujung pada gerakan terorisme. Sebab, seakan-akan agama membenarkan untuk membunuh orang kafir dan membolehkan memerangi orangorang yang dianggap tidak beriman atau tidak beragama dengan benar. Dapat dikatakan bahwa munculnya radikalisme disebabakan oleh cara pandang atau wawasan yang sempit terhadap agama. Pola pikir normatif dan pola pikir hitam putih merupakan faktor dominan lahirnya radikalisme dan terorisme. Sejarah Islam mencatat bahwa akibat polapikir yang sempit terhadap terminologi kafir, maka seorang ulama besar yang hafal Al-Qur'an, rajin shalat malam, dan rajin puasa sunah SeninKamis yang bernama Abdurrahman bin Mulzam tega membunuh Sayidina Ali bin Abi Thalib karena Sayidina Ali bin Abi Thalib dianggap kafir atau tidak beragama secara benar hanya gara-gara melakukan perundingan damai dengan Muawiyah.

Radikalisme dalam agama akhirnya menjalar ke aspek pendidikan, dimana salah satu atau beberapa elemen dalam pendidikan sering melakukan radikalisme yang menyebabkan teror atau rasa takut para elemen pendidikan untuk melaksanakan tugas sebagai pendidik dan tenaga kependidikan. Guru kurang maksimal melaksanakan tugasnya sebagai pendidik hanya agara gara takut diancam pihak pihak lain uangg dianggap merasa dirugikan. Seorang kepala sekolah kurang optimal menjalankan tugasnya sebagai pimpinan lembaga pendidikan karena takut ditekan atau diancam oleh atasannya. Akibatnya proses 
pendidikan dan proses kepemimpinan kurang sesuai harapan karena ada intervensi yang bersifat mengancam dari pihak pihak lain diluar pendidikan.

\section{Bentuk-bentuk Radikalisme dalam Pendidikan}

Radikalisme dapat dikatakan suatu faham atau cara fikir yang menjadi landasan untuk melakukan geralan kriminal atau teror meskipun dilihat akar sejarahnya radikalisme bersifat positif. Dalam dunia pendidikan tidak bisa terhindar dari fenomena fenomena kekerasan yang menjadikan tujuan pendidikan gagal di raih. Radikalisme bisa muncul dari berbagai elemen dalam pendidikan. Secara umum fenomena radikalisme dalam pendidikan lahir dari guru kepada siswa, dari siswa kepada guru dan juga dari orang tua/masyarakat kepada elemen elemen yang ada di dalam pendidikan.

Berdasarkan catatan Harian Bali Post bahwa Selama tahun 2010-2014 tercatat gerakan kekerasan yang terjadi di lembaga pendidikan sebanyak 21.689.797 (bali post 14 mei 2015). Bentuk bentuk kekerasan tersebut dialami oleh siswa ataupun guru.

M. Saekan Muchith (2007) dalam buku Pembelajaran Kontekstual menjelaskan bahwa fenomena atau fakta kekerasan yang dapat dipahami sebagai bentuk radikalisme bisa dilihat dari beberapa kasus antara lain; Di Magelang, siswa SD di tempeleng gurunya hanya gara gara siswa menyela pembicaraan guru yang sedang memberi pengumuman acara pertunjukan sulap. Di Tanjing pinang ada oknum guru olahraga menendang siswanya saat pembelajaran dengan alasan mendidik. Di Kabupaten Takalar Sulawesi Selatan para guru mogok mengajar karena alasan salah satu guru agama di sekolah tersebut di penjara 6 bulan gara gara memukul siswanya. Aksi mogok mengajar dimaksudkan sebagai aksi protes agar oknum guru agama yang dipenjara/tahan di bebaskan.

Bentuk radikalisme dalam pendidikan tidak semuanya berupa aksi kekerasan, tetapi juga dapat diwujukan dalam bentuk ucapan dan sikap yang berpotensi melahirkan kekerasan yang tidak sesuai dengan norma-norma pendidikan. Sikap yang berpotensi melahirlan kekerasan tersebut berimplikasi kepada 


\section{Saekan Muchith}

munculnya situasi dan kondisi sekolah yang tidak menyenangkan bagi siswa dalam belajar. Peran atau fungsi sekolah yang memiliki fitrah membimbing, mengarahkan siswa, tempat bermain dan belajar anak anak sekarang sudah berubah atau bergeser menjadi lembaga yang menakutkan, mencemaskan, menegangkan, bahkan menyiksa lahir dan batin para siswa. Mengapa demikian? Karena orientasi pendidikan sudah berkurang yang awalnya sebagai bagian datinproses penyadaran menjadi proses pemaksaan dalam mengetahui, memahami dan mengembangkan ilmu pengetahuan.

Perubahan situasi dan lingkungan serta suasana pendidikan yang melahirkan perubahan orientasi tersebut bukanlah tanpa sebab. Justru perubahan atau pergeseran itu merupakan akibat dari perkembangan atau dinamika budaya yang menerpa masyarakat. Artinya masing masing elemen dalam pendidikan tidak mampu mengambil nilai nilai positif atau manfaat akinat perkembangan ilmu pengetahuan, teknologi dan kebudayaan. Mayoritas masyarakat justru mengambil makna negatif dari perubahan dan perkembangan ilmu pengetahuan, teknologi dan kebudayaan. Misalnya, geralan reformasi yang tujuannya sangat mulia untuk menegakkan aturan dan keadilan malah menjadi ajang saling "pembantaian" sosial. Transparansi yang dimaksudkan untuk sarana pertanggung jawaban tugas dan perannya malah berubah menjadi ajang mencari cari kesalahan orang lain yang akhirnya menyengsarakan pihak pihak tertentu. Sikap humanis atau memanusiaan orang lain yang dimaksudkan sebagai bagian dari upaya saling menghargai dan menghormati malah berubah menjadi realitas saling menyepelekan yang berujung tidak ada kepatuhan satu dengan lainnya.

Etika dan sopan santun yang seharusnya dijunjung tinggi semua pihak, tetapi di lembaga pendidikan seperti sekolah seakan akan tidak ada lagi saling hormat antar guru, antara siswa kepada guru dan antara guru dengan pimpinan. Siswa instan, sekolah serba mudah, cepat dan meraih hasil yang memuaskan. Guru juga selalu mengharap pekerjaan yang serba mudah sehingga terkesan tidak mau repot dalam menjalankan tugas dan fungsinya sebagai 
pendidik. Orang tua yang seharusnya mendukung penuh proses pendidikan dan pembelajaran anaknya disekolah juga terkesan kurang perhatian atau kurang mendukung sehingga seolah olah sekolah dibiarkan menjalankan tugas tugas pendidikan.

Berbagai fenomena budaya yang cenderung negatif tersebut, secara pelan pelan melahirkan kebiasaan yeng berakibat tidak atau kurang menghargai profesi dalam pendidikan. Guru dan sekolah sebagai lembaga lembaga pendidikan sangat mudah di lecehkan oleh siswa dan orangtua siswa atau masyarakat. Tidak sedikit siswa yang dengan mudah secara langsung maupun tidak langsung melakukan ancaman kepada gurunya yang notabenenya telah mendidik dan mengajar mereka jika sewaktu waktu siswa mengalami perlakuan yang kurang mengenekkan. Orang tua siswa atau masyarakat begitu mudah dan cepat menyalahkan guru atau pihak sekolah jika mendapatkan anaknya memperoleh perlakuan yang tidak menyenangkan dari pihak guru atau sekolah. Atas nama hukum dan keadilan siswa ataupun orangtua siswa selalu menempuh jalur hukum dalam menyelesaikan persoalan yang terjadi di dalam proses pendidikan dan pembelajaran. Apa implikasi dari fenoemana tersebut? Diakui atau tidak, guru dan pihak sekolah akan berfikir panjang ketika akan melakukan pembinaan kepada siswanya meskipun siswa ya diketahui akan "nakal" atau "ndableg" atau kurang memiliki motivasi dalam belajar. Dengan kata lain guru sering kali menerima ancaman hukum pidana umum jika dianggap telah melakukan perbuatan yang tidak menyenangkan pihak siswa atau orang tua.

Undang undang nomor 14 tahun 2005 pasal 39 ayat 1-5 secara jelas dan eksplisit bahwa guru minimal memperoleh toga macam perlindungan yaitu perlindungan hukum, perlindungan profesi dan perlindungan keselamatan dan kesehatan kerja. Perlindungan hukum adalah perlindungan dari segala macam ancaman tindak kekerasan, intimidasi, perlakuan diskriminatif dari peserta didik, orang tua peserta didik, masyarakat, birokrasi atau pihak lain. Perlindungan profesi adalah perlindungan dari perilaku pihak lain yang tidak sesuai peraturan perundang undangan yang terkait dengan menjalankan tugas profesi, misalnya pemutusan 


\section{Saekan Muchith}

hubungan kerja, pemberian imbalan atau penghargaan yang tidak wajar, pembatasan dapam penyampaan pandangan, pelecehan profesi dan sehala bentuk pelarangan yang menghambat guru mengembangkan karir profesinya. Perlindungan keselamatan dan kesehatan kerja adalah perlindungan dari berbagai bentuk gangguan keamanan kerja, keselamatan dan kesehatan kerja.

Aturan yang sudah sangat jelas atau terang benderang sampai sekarang belum bisa dilaksanakan secara optimal. Para guru masih diposisikan lemah terutama pada saat menjalankan tugas profesinya. Karena sikap dan perilaku guru saat menjalankan tugas profesinya tidak diselesaikan menggunakan aturan etika profesi tetapi langsung diselesaikan menggunakan aturan hukum peradilan pidana umum. Inilah sumber sekaligus bentuk dati lahirnya radikalisme dapam dunia pendidikan.

\section{Mengeliminir Radikalisme}

Radikalisme bisa menimpa siapa saja, kapan saja dan dimana saja. Tidak peduli anak anak, remaja, orang dewasa, tidak pandang mereka miskin atau kaya, tidak pandang mereka kelompok elit ataupun rakyat jelata. Radikalisme lebih banyak disebabkan oleh adanya faham atau pemikiran yang sempit terhadap suatu fenomena. Oleh sebab itu radikalisme alan bisa ditelan atau dieliminir bahkan dihilangkan hatus diawali dati pembinaan atau bimbingan cara pandang atau cara fikir terhadap suatu fenomena. Nur Syam (2009) dalam buku Tantangan Multikulturalisme Indonesia memiliki analisis yang cukup menarik bahwa untuk melahiroan cara pandang yang tepat perlu belajar dari ideologi ahlussumah wal jamaah atau NU yang dicirikan dengan empat hal;

Pertama, tawasuth (moderat). Doktrin ini mengajarkan bahwa manusia memiliki kebebasan untuk melaksanakan suatu aktivitas tetapi sebebas apapun manusia masih dibatasi oleh kehendak Tuhan Yang Maha Kuasa. Artinya dapam meraih keuksesan, manusia wajib ihtiyar secara optimal tetapi jangan lupa bahwa Allah swt juga ikut menentukan keberhasilan. Setelah berusaha manusia wajib berdoa dan pasrah kepada Allah swt.

Kedua, tawazun ( keseimbangan). Doktrin ini mengajarkan bahwa manusia dalam memandang suatu realitas tidak boleh 
bersifat ektrem baik kekiri atupun ke kanan. Artinya manusia yang bauk tidak terlalu berlebihan pada saat senang atau benci kepada sesuatu. Hal ini didasarkan asumsi bahwa sebaik baik menurut pandangan manusia belum tentu baik menurut Allah swt, sebaliknya sejelek jelek dalam pandangan manusia juga belum tentu jelek menurut Allah swt.

Ketiga, itidal (keadilan). Doktrin ini mengajarkan bahwa diantara sesama manusia harus saling memebrikan kepercayaan dan kepercayaan yang dibangun harus memberikan persn secara proporsional. Dunia akan cepat hancur jika masing masong elemen tidak memiliki kesadaran untuk melaksanakan peran masing masing secara proporsional.

Keempat, tatharruf(universsalisme). Doktrininimengajarkan Setiap manusia agar lebih mengedepankan pemahaman islam yang bersifat universal (global). Kebenaran Islam dilihat dari norma norma yang bersifat umum seperti keadilan, kemanusiaan, keselamatan dan kesejahteraan.

Langkah berikutnya yang bisa dilakukan untuk mengeliminir atau membendung gerakan radikalisme dalam pendidikan adalah dengan cara memerkuat pola jaringan kerjasama internal sekolah dan jaringan eksternal antara sekolah dengan masyarakat dan orang tua siswa. Kerjasama internal adalah kerjasama yang rapi dan kompak antara pimpinan kepada guru, antar sesama guru dalam menghadapi, memahami dan menyelesaikanersoapan siswa. Lengkah langkah yang dilakukan antara guru satu dengan lainnya, antara pimpinan satu dengan yang lain harus singkron sehingga tidak muncul kesan berbeda beda dalam melihat persoalan siswa. Kerjasama antar sekolah dengan masyarakat dan orang tua adalah pola koordinasi secara rutin dan sistematis jika terdapat persoalan yang muncul. Kerjasama dilakukan sesuai dengan jenis problem dan kepentingan yang ada, dan kerjasama tidak hanya dilakukan dalam konteks memberikan solusi atas persoalan yang muncul tetapi juga harus dilakukan dengan tujuan antisipasi atau pencegahan mumculnya persoalan dalam pendidikan.

Ada kesan sekolah atau pendidikan dipinggirkan dalam artian jika ada persoalan yang muncul, semua sebab musabab 


\section{Saekan Muchith}

dianggap hanya dari kelemahan elemen elemen yang ada di sekolah. Akibatnya semua elemen menumpakan penyelesaian persoalan seakan akan menjadi tugas dan tanggung jawab sekolah. Sekolah atau lembaga pendidikan merupakan open system yaitu suatu sistem tata organisasi yang sangat terbuka sehingga sangat mudah dipengaruhi oleh pihak pihak luar. Artinya apa yang terjadi di dalam sekolah atau lembaga pendidikan terdapat faktor dominan dari pihak luar pendidikan. Oleh sebab itu dalam penyelesaiannya juga harus bersifat utuh dan komprehensif.

Secara tehnis regulatif, untuk mengeliminir lebih meningkatnya gerakan radikalisme dalam pendidikan dapat dilakukan dengan caravmengoptimalkan atau melaksanakan secara sungguh sungguh amanah undang undang nomor 14 tahun 2005 tentang guru dan dosen khususnya pasal tentang perlindungan. Sebagai salah satu profesi, guru dalam menjalankan tugasnya harus diberikan tiga jenis perlindungan seperti yang tercantum dalam pasal 39 ayat 1-5 sehingga guru dalam menjalankan tugasnya merasa nyaman dan aman. Jika pasal tersebut diberlakukan maka pihak pihak lain tidak bisa serta merta melakukan penyelesaian melalui peradilan pidana umum. Apa bila guru melakukan hal hal yang dianggap kurang tepat dalam waktu menjalankan tugas profesi atau di dalam proses pembelajaran dan pendidikan maka harus diselesaikan melalui undang undang profesi yang ditegakkan oleh dewan kehormatan etika profesi.

\section{Simpulan}

Radikalisme dalam pendidikan memiliki potensi ancaman yang sangat berbahasa dalam mewujudkan kelangsungan kualitas pendidikan. Radikalisme bisa muncul kapan saja, dari mana saja dan dapat dilakukan oleh siapa saja. Oleh sebab itu radikalsime perlu di sikapi secara utuh dan komprehensif yang meliputi berbagai aspek melakukan sinergi secara rapi dan tepat.

Radikalisme menyangkut persoalan cara pikir, kepribadian dan sikap perilaku, oleh sebab itu cara untuk mengeliminir munculnya radikalisme dimulai dari pemahaman yang kontekstual 
dalam melihat fenomena yang ada di dapam kehidupan sosial. Cara pikir dan kepribadian tawazun, moderat dan mengedepankan kebenaran universal adalah langkah pertama dan utama untuk mengeleminir gerakan radikalisme.

Langkah teknis lainnya berbagai elemen pendidikan yang berwewenang harus segera melakukan langkah langkah strategis dan teknis untuk menyusun peraturan tentang perlindungan guru, agar guru tidak mudah memperoleh perlakuan yang dikriminatif, ancaman dari pihak manapun. Dengan pemberlakuan peraturan perlindungannmaka guru dapam menjalankan tugasnya juga tidak akan sewenang wenang kepada siapapun terutama kepada Peserta didik. Pemberlakuan peraturan pemberlakuan perlindungan guru harus diimbangi dengan kerjasama intensis, utuh dan menyeluruh dari berbagai pihak sehingga dalam realitasmya benar benar sesuai harapan yaitu menangkal atau menghilangkan radikalisme dalam pendidikan. 
M. Saekan Muchith

\section{DAFTAR PUSTAKA}

Bahrudin, Ahmad, Pendidikan Alternatif Qaryah Thoyyibah, Yogyakarta: LKiS, 2007.

Muchith, M. Saekan, Ilmu Pendidikan Islam, Kudus: STAIN Kudus Press, 2007. , Pembelajaran Kontekstual, Semarang: Rasail, 2008. , Pendidikan Tanpa Kenyataan, Semarang: Unnes Press, 2008.

Prihantoro, Agung, Politik Pendidikan kebudayaan, Kekuasaan dan Pembebasan, REaD, Yogyakarta: Pustaka Pelajar, 1999.

Purwanto, M. Ngalim, Ilmu Pendidikan Teoritis dan Praktis, Bandung: Rosdakarya, 1995.

Suparno, Paul, Teori Perkembangan Kognitif Jean Piaget, Yogyakarta: Kanisius, 2001.

Syam, Nur, Tangangan Multikulturalisme Indonesia, Yoyakarta: kanisius, 2009.

Turmudzi, Endang dan Riza Sihbudi (ed)., Islam dan Radikalisme Di Indonesia, Jakarta: LIPI Press, 2005. 